Article

\title{
Religious Identity and Public Pro-Environmental Behavior in China: The Mediating Role of Environmental Risk Perception
}

\author{
Sheng Zeng ${ }^{\mathbb{D}}$, Lin $\mathrm{Wu}^{*}$ and Tianyuan Liu \\ School of Sociology, Wuhan University, Wuhan 430072, China; zengs372@whu.edu.cn (S.Z.); \\ ltyuan@whu.edu.cn (T.L.) \\ * Correspondence: wlin@whu.edu.cn
}

Received: 3 February 2020; Accepted: 30 March 2020; Published: 1 April 2020

check for updates

\begin{abstract}
Although the positive relationship between religion and environmental behavior has aroused heated debate, empirical research on the relationship between religion and public pro-environmental behavior is still relatively insufficient. This paper aims to explore the group differences in the influence of religious identity on public pro-environmental behavior and the mediating role of environmental risk perception in religious identity and public pro-environmental behavior. Using the Chinese General Social Survey data of 2013 for empirical analysis, this study's results show that there are group differences in the impact of religious identity on public pro-environmental behavior. Women with a religious identity are more willing to engage in public pro-environmental behavior than those without a religious identity. Additionally, people over the age of 45 with a religious identity are more willing to participate in public pro-environmental behavior than those without a religious identity. Furthermore, political participants with a religious identity are more willing to practice public pro-environmental behavior than those without a religious identity. In addition, we found that environmental risk perception can act as partial mediation in religion and public pro-environmental behavior. In other words, religious identities are deeply embedded in local political and social culture. In order to correctly understand the relationship between religion and public pro-environmental behavior, it is necessary to consider religious identity in a specific cultural background.
\end{abstract}

Keywords: religious identity; public pro-environmental behavior; environmental risk perception; China

\section{Introduction}

Over the past 40 years of reform and opening up, China has faced an unprecedented environmental crisis. Rapid population expansion and economic growth have caused the largest "environmental disaster" in history. The unilateral emphasis on economic development has increased the level of "turbidity" in modern social spaces to a degree not comparable in the history. Air pollution, water pollution, marine pollution, solid waste pollution, and toxic pollution have spread endlessly throughout society. Water resource shortages, land desertification, acid rain, agricultural land depletion, and animal extinction have mercilessly swept through the social space (Harris 2006). At the end of 2019, some experts from China said that a unique species of the Yangtze River-the Yangtze River paddlefish-had become extinct and there are still species in danger of extinction. Obviously, the extinction of species is closely related to the destruction of the ecological environment. In order to prevent a further deterioration of ecology, the government has implemented a ten-year fishing ban in the Yangtze River beginning 1 January 2020. The severity of environmental problems and the urgency of environmental protection are clearly evident in China. The environmental problems have attracted 
the attention of political and academic circles. President Xi said that "lucid waters and lush mountains are invaluable assets" (Xi 2013). This means that we must learn to conform to nature, protect nature, and live in harmony with the nature. Since 2019, many cities in China have begun to introduce waste classification policies. At present, environmental governance has become an important part of social governance. Some scholars have suggested that individual knowledge, belief, and attitude have an important impact on the ecological environment (Maloney et al. 1975). The human environmental paradigm (HEP) holds that human beings are not bound by natural laws, environmental resources are inexhaustible, and the natural environment is a means and tool for human beings to achieve their own goals (Catton and Dunlap 1978). This causes large-scale destruction of the natural environment by human beings. A new environmental paradigm (NEP) holds that human activities are closely related to the natural environment (Dunlap and Liere 2008; Dunlap et al. 2000). Human beings are a part of the natural world and are governed by the same rules as the rest of the nature-for example, the rules of the interdependence of species (Corral-Verdugo and Armendariz 2000). At present, the novel coronavirus pneumonia, which is spreading all over the world, illustrates the profound influence of nature on mankind. The spread of this concept coincided with the emergence of many environmentalists. A previous study shows that gender, age, working status, education, residence, etc., have an important impact on environmental behavior, and that women, and young, employed, highly educated, urban, and single people are more willing to participate in environmental behavior (Chen et al. 2011). Some scholars divide environmental behavior into public pro-environmental behavior and private pro-environmental behavior, and they suggest that public pro-environmental behavior displays no significant difference in different countries, but that private pro-environmental behavior is heavily influenced by local conditions, in which politics and resources are two important factors (Hadler and Haller 2011).

Since the 1960s, the relationship between religion and the environment has attracted wide attention in academic circles (Berry 2013). Generally speaking, global religions can be roughly divided into two camps: Eastern religions and Western religions. Because of the differences in the deep structure of Eastern and Western cultures, these two camps display great differences. In particular, most Eastern religions are polytheistic. Whether Buddhism, Daoism, or Shitoism, they all have one thing in common; that is, there are many gods and even pan gods. These gods do not interfere with each other and coexist harmoniously in the process of development ( $\mathrm{Li}$ and Chen 2010). Eastern religions are more diffused religions which generally have a lower exclusivity (Lu 2008). The purpose of people's belief in Eastern religion is more to pray and live a better life. If the deity they worship does not work for them, they may choose to worship another deity to a large extent. In other words, it is relatively easy for believers to converse religion and they can believe in many gods at one time ( $\mathrm{Lu}$ 2008). Most importantly, most Eastern religions include the unity of God and mankind, and the belief that they can transform each other in many times (Tong 2005). Compared with Eastern religions, Western religions are monotheistic; whether Christianity, Judaism, or Islam, they believe in a single god. These religions have been more exclusive to other religions in the process of historical development. Besides, the relationship between God and mankind is the opposite and not unified. The main purpose of life in the world is to obtain God's salvation (Li and Chen 2010). In other words, Western religious believers are more utilitarian (Zhang 2016). It has also been noted that people who believe in Western religions will not easily change their religious beliefs ( $\mathrm{Lu} 2008$ ).

Historian Lynn White (1967) pointed out that Jewish Christianity's moral concept of nature caused an ecological crisis. There are different opinions in academic circles in response to this judgment. Some scholars suggest that Lynn White's opinion is well-founded. It is clearly written in Genesis: "...Then God said: 'Let us make man in our image, in our likeness, and let them rule over the fish of the sea and the birds of the air, over the livestock, over all earth, and over all creatures that move along the ground'" (Genesis 1.26). To realize the glory of God, humans must learn to control nature (Hayes and Marangudakis 2000). Eckberg and Blocker (1989) also further confirmed the destructive impact of Christianity on the environment. Some scholars hold the critical view on Lynn White's opinion 
that although Christianity has a negative effect on the environment, many liberals and moderates still have a positive attitude toward environmental protection. For example, the Southern Baptist Convention has begun to advocate that members be good stewards of nature (Sherkat and Ellison 2007). Since the mid-1990s, many observers have claimed there has been "Christianity greening" in the United States. Some environmentalists (Haluza-Delay 2000; Hoffman and Sandelands 2005), religious scholars (Kearns 1996; Wallace 2008), and religious leaders (Beisner 2001; Harper and Kennealy 2009) believe that empathy for the environment is essentially consistent with Christian values, even if it is not required by Christian values. Using the 2010 General Social Survey data (GSS), researchers found that the environmental concerns of those who self-identify as Christians in terms of pro-environmental behavior are lower than those of non-Christians. Self-identification with Christianity has a positive effect on pro-environmental behavior, but not on pro-environmental attitude and belief (Clements et al. 2014). Some scholars have pointed out that there is a complex relationship between religion and politics. For example, the connection between fundamentalism and politics makes the interpretation of the effect of religion on environmental beliefs more complicated, because political conservatism is negatively correlated with environmentalism (Sherkat and Ellison 2007; Woodrum and Wolkomir 1997). Pickering and Jewell (2008) also found a close connection between belief, politics, and the environment in their study on the indigenous Kolata community. With the help of these three elements, the indigenous Kolata community has realized the connection of spiritual value. Some scholars divide environmentalism into problematic environmentalism and moral environmentalism. Most religious groups think that their pro-environmental behavior is a kind of moral environmentalism, which is based on the connection between God and nature and emphasizes action, community, and justice (Smith and Pulver 2009).

Religion and environmental behavior do not have a simple linear relationship. Moral concepts, doctrines, and social networks may be the potential factors through which religion influences environmental behavior. Risk perception also plays an important role in religion and environmental behavior. Risk perception is a psychological concept that was proposed by Slovic and aims to explain how social risk is perceived by the public (Slimak and Dietz 2006; Slovic 1999). With the occurrence of risk events, risk perception of the public has become a hot issue in academia (Bubeck et al. 2012; Slimak and Dietz 2006; Slovic and Peters 2006). On the one hand, some scholars have found that risk perception has a positive impact on individual behavior. For example, some scholars believe that there is a positive relationship between flood risk perception and the willingness of individuals to undertake private mitigation measures (Baan and Klijn 2004; Plapp and Werner 2006; Plattner et al. 2006; Terpstra et al. 2009). It has been further proven that flood risk perception is the most dominant factor driving private mitigation (Bubeck et al. 2012). Besides, some scholars have found that there is a certain relationship between risk perception and environmental behavior. For instance, O'Connor et al. (1999) believed that risk perception plays an important role in predicting behavioral intention in a study on risk perception and willingness to cope with climate change. When we discuss the personal risk in multiple disaster conditions, risk perception in behavioral decision-making will play an important role (Lindell and Hwang 2008). There is no doubt that there is a close relationship between risk perception and individual behavior. According to the theory of protection motivation, when facing risk events, people take defensive measures to reduce the risk. It is clear that risk perception and individual behavior correspond to each other. Obviously, when we have a high risk perception of the environment, we will pursue some environmental behaviors to reduce our risk perception of the environment. Therefore, risk perception is an important predictor of pro-environmental behavior. On the other hand, some scholars have also found that there is a certain relationship between risk perception and religion. Some scholars have studied the volcano risk perception in Italy and found that religious perspectives are still important features of the way in which people in many societies perceive the risk of volcano eruptions (Chester et al. 2008). Some scholars have found that religious people are conceived as risk-averse and non-religious people are conceived as risk-taking (Miller and Hoffmann 1995; Noussair et al. 2013). When faced with high risks, religious people will take the initiative to avoid risks, no matter what behavior is practiced. In other words, risk perception plays a moderating role 
between religion and risk aversion. In a word, risk perception is very important for religious people in terms of avoiding risks and the public in terms of practicing pro-environmental behavior. On this basis, it makes us wonder what the role of risk perception is in the relationship between religion and pro-environmental behavior.

According to incomplete statistics, religious people account for $59 \%$ of the global average level (Win-Gallup International 2012), and Christianity accounts for 3/4 of the total population of North America and Europe (Pew Research Center 2012). It can be seen that religious people account for the vast majority of the global population and have deeply influenced the trend of global environmental governance. China, by contrast, has the smallest share of religious people, who only account for $14 \%$ of the total population in China (Win-Gallup International 2012). The results of the China Family Panel Studies show an even lower percentage, with religious people only accounting for $10 \%$ of the total population in China (CFPS 2012). However, China is a super-state with a total population of 1.4 billion. The scale and function of religious people in China cannot be underestimated. A typical example has been given by Jianyong Jiang, the deputy director of the National Religious Affairs Administration, who suggested that traditional Chinese religion plays an important role in environmental protection (Xinhua 2016). The state Administration for Religious Affairs (SARA) of China proposed the concept of an "ecological temple", which plays a positive role in promoting religion participation in environmental protection (SARA 2014). In recent years, Chinese religion has done a lot of practice in the field of environmental protection. For example, the Chinese Taoist Association (2009) published Eight-Year (2010-2017) Planning for Environmental Protection, and religious groups have participated in some important international conferences on environmental protection and environmental protection actions. However, from the perspective of current research, studies of religion's role in environmental behavior mainly proliferate in Western academic circles, especially those exploring the impact of Christianity on environmental behavior. Although a few scholars have begun to explore the internal relationship between religion and environmental behavior, on the whole, research on religion and environmental behavior still seems to be relatively insufficient in Chinese discourse. Exploring the relationship between religion and environmental behavior in China and rooted in Chinese culture is not a simple replication of relevant research in the Western world. It is an effective supplement that diversifies academic research. China is an atheist country. The Communist Party of China, as the ruling party, is a firm supporter of materialism. In national political and ideology education, socialist values and materialistic ideals are firmly instilled in the public. This special political background provides a growing environment for Chinese religion, and the political and cultural differences between China and the West make it necessary to study the relationship between Chinese religion and environmental behavior.

At present, research concerning religion and environmental behavior in China mainly focuses on three aspects. First, the mechanism of religion and the environment. For example, some scholars have studied how religious beliefs in rural communities in Tibetan areas affect environmental behavior. The researchers have pointed out that religion can restrain villages' environmental destruction through deifying the landscape, instilling the concept into villages that killing animals and plants is evil, and using the moral norms embodied in Buddhist doctrine (Woodhouse et al. 2015). Using listed companies in polluting industries in 2008-2010 as samples, researchers found that the social rules embodied in Buddhism can awaken the awareness of social responsibility and enhance corporate social responsibility (CSR) (Du et al. 2014). The second aspect is the internal relationship between Chinese religion and the environment. Xing and Starik (2017) studied the relationship between Taoism and nature and suggest that Taoism regards humans and nature as a harmonious and unified whole. The attitude of Taoism leaders toward nature is not to control nature, but live in harmony with nature. The Confucian concept of "tianren heyi" closely combines nature and humans and provides theoretical and practical guidance for our understanding of the human position in the universe, the harmony between humans and nature, and the value of environmental protection and conservation (Yao 2014). Third, researchers have tried to use empirical data in China to test the influence of religion on environmental 
behavior. Some scholars found that religious beliefs have a significant positive effect on public pro-environmental behavior, but no significant positive effect on private pro-environmental behavior, after dividing comprehensive environmental behavior into private pro-environmental behavior and public pro-environmental behavior (Yang and Huang 2018).

Pro-environmental behavior in China is deeply shaped by its complex religious traditions (Miller et al. 2014). It has been shown that religion is an important factor that cannot be ignored in the practice of pro-environmental behavior. However, it has also been noted that research on the impact of religion on environmental behavior is still relatively rough and needs to be further enriched and expanded by future scholars. Additionally, we believe that environmental behavior also needs to be further classified and expanded. There are differences in the role and influencing mechanisms of different environmental behavior, which must be discussed separately. Besides, because religious belief is more or less a private and unobserved phenomenon and religious identity is a collective, public, group-oriented, and observable measure. From this point of view, the religion we gauged in the CGSS 2013 is more about the predictor of religious identity. In this article, we mainly use religious identity as a predictor of religion and try to study the group differences in the influence of religious identity on public pro-environmental behavior and the influencing mechanism of religious identity on public pro-environmental behavior by using empirical data from China.

\section{Data and Measures}

\subsection{Data}

The data we used in this article is from the 2013 version of the Chinese General Social Survey (CGSS 2013), which has been a member (on behalf of the mainland) of the International Social Survey Program (ISSP) since 2007 (Yang and Huang 2018). The Chinese General Social Survey conducted by the National Survey Research Center at Renmin University of China (NSRC) started in 2003 and is the earliest national, comprehensive, and continuous academic survey project in China. Since 2003, the NSRC has conducted a continuous cross-sectional survey on more than 10,000 households in various provinces, municipalities, and autonomous regions in China, which has comprehensively collected data from multiple levels, including society, community, family, and individual levels. In order to ensure the validity, authenticity, representativeness, and accuracy of the data, the CGSS 2013 adopted objective sampling, including phased sampling, stratified sampling, and cluster sampling. It also employed a professional investigator and supervised inspections, etc., to ensure the quality of the data. The CGSS 2013 covered 487 communities in 28 provinces, autonomous regions, and municipalities, excluding Taiwan, Hong Kong, and Macau. The respondents were mainly adults over 16 years old. The project collected individuals' demographic characteristics, such as gender, age, ethnicity, religion, education, income, political status, housing status, marital status, etc., and other information related to the study, including environmental knowledge, environmental risk perception, and environmental behavior. This study collected a total of 11,438 samples and yielded a final sample of 9144 after deleting invalid samples, such as "refused to answer", "unanswerable", and "singular value".

\subsection{Independent Variable}

Religion is a sensitive subject in China, which makes it difficult to quantify. According to this study, the religion we gauged in the CGSS 2013 is the core variable. The items included "no religion", "Buddhism", "Taoism", “Folk belief (Matsu worship, Guangong, etc.)", "Islam", "Catholicism", "Christianity", “Orthodox", “Other Christianity", "Judaism", “Hinduism”, and "other.” Respondents could choose one or more items. First, we constructed a dichotomous measure via a survey question asking respondents whether they self-identified with "no religion" or "religion" and which religion they self-identified with if they had a religious identity. Second, we assigned respondents that had "no religion" a value of 0 and assigned respondents that had "religion" a value of 1 (religion including Buddhism, Taoism, Folk (Matsu worship, Guangong, etc.), Islam, Catholicism, Christianity, Orthodox, 
Other Christianity, Judaism, or Hinduism). In addition, we deleted the items for which respondents answered "Other". Finally, we obtained "religious identity" as the independent variable of this study, according to the above methods.

\subsection{Mediating Variable}

We selected the question, "How serious are the following types of environmental problems in your area?" which included 12 environmental problems reflecting the mediating variable of the study. The environmental question items that respondents needed to respond to included "Air pollution", "Water pollution", "Noise pollution", "Industrial waste pollution", “Domestic waste pollution", "Insufficient green space", "forest vegetation destruction", "Cropland quality degradation", "Fresh water shortage", "Food pollution", "Desertification", and "Wildlife deduction." Respondents could rate the extent of the answer as "Very serious", "Relatively serious", "Less serious", "Not serious", "Fair", "Don't care/Unclear", or "No such problem." To ensure the consistency of the research, we assigned a value of 1, 2, 3, 4, 5, 6, and 7 to the respondents who answered "No such problem", "Don't care/Unclear", "Fair", "Not serious", "Less serious", "Relatively serious", and "Very serious", respectively. To ensure the objectivity and integrity of the data, we handled missing values by sequential mean interpolation. Finally, we used the total score of the 12 environmental problems after being processed as a measure of the environmental risk perception (ERP). The higher the above score, the higher the degree of ERP.

\subsection{Dependent Variable}

We selected the question, "We want to know, in the past year, have you engaged in the following activities or behaviors?", which included ten environmental behaviors. First, we performed a factor analysis on these 10 items, and then, we extracted two factors, including private pro-environmental behavior (Private PEB) and public pro-environmental behavior (Public PEB). In this study, we also found that religious identity does not have a significant positive effect on pro-environmental behavior in the private domain $(\beta=0.037, p>0.05)$. Therefore, we mainly focused on the complex relationship between religious identity and pro-environmental behavior in the public domain. Public pro-environmental behavior included the following five items: "(5) Donate for environmental protection", "(7) Actively participate in environmental education organized by governments and work units", "(8) Actively participate in environmental protection activities organized by private environmental protection groups", "(9) Conserve forests and green spaces at their own expense", and "(10) Actively participate in complaints and appeals that require environmental issues to be resolved." We assigned a value of 1, 2, and 3 to the respondents who answered "Never", "Occasionally", and "Often", respectively. Finally, we used the aggregated scores of the five items as the indicators of public pro-environmental behavior. The higher the score of public pro-environmental behavior, the more willing respondents are to conduct public pro-environmental behavior.

\subsection{Control Variable}

Based on the availability of data and drawing on existing research, we controlled variables that could affect public pro-environmental behavior, including gender, age, ethnicity, education, hukou, income, political status, housing status, working status, marital status, health, and environmental knowledge (EK). To facilitate statistics and analysis, in terms of gender, we assigned "Female" a value of 0 and "Male" a value of 1 . In terms of age, we assigned a value of 0,1 , and 2 to "Under 44", "45-59", and "Over 60", respectively. In terms of ethnicity, we assigned "Minority" a value of 0 and "Han" a value of 1 . For education, we assigned a value of $0,1,2$, and 3 to "Primary and below", "Junior high school", "Senior high school", and "College and above", respectively. For income, we took the total annual income as a logarithmic measure. For political status, we assigned "Non-Chinese Communist Party Members" a value of 0 and "Chinese Communist Party Members" a value of 1 . In terms of housing status, we assigned a value of 0,1 , and 2 to "Residence belongs to myself or my spouse", "Residence belongs to parents or child", and "Residence belongs to others", respectively. For working 
status, we assigned "No Working" a value of 0 and "Working" a value of 1 . In terms of marital status, we assigned "Unmarried" a value of 0 and "First marriage with spouse", "Remarriage with spouse", "separation without divorce", "divorce", and "widowed" a value of 1 . For health, we assigned a value of 1, 2, 3, 4, and 5 to "Very unhealthy", "Less healthy", "Generally healthy", "Healthier", and "Very healthy", respectively.

Lastly, we selected the question "Finally, we want to know your mastery of environmental protection knowledge", which included ten items as indicators of environmental knowledge. The items that respondents needed to answer included "Car exhaust does not pose a threat to human health"; "Excessive use of fertilizers and pesticides causes environmental damage"; "Using phosphorous laundry powder does not cause water pollution"; "Fluorine emissions from fluorine-containing refrigerators does not deplete the ozone layer of the atmosphere"; "There is not relationship between the generation of acid rain and coal burning"; "Species are interdependent, and the disappearance of a species will have a chain reaction"; "In the air quality report, third-class quality means better than first-class air quality"; "Single species of trees are more likely to cause diseases and insect pests"; "In the water pollution report, V(5) water quality means better than I(1) water quality"; and "The increase of carbon dioxide in the atmosphere is a factor of causing climate warming." We assigned "Correct" a value of 1 and "Wrong" or "Do not know" a value of 0 . Finally, we used the aggregated scores of the ten items as the indicator of environmental knowledge (EK). The higher the score, the higher the degree of mastery of environmental knowledge.

\section{Results}

\subsection{Descriptive Analysis of Social Demographic Characteristics}

As shown in Table 1, there are 976 religious people in the 9144 valid samples, accounting for about $10.67 \%$ of the total sample. This is roughly consistent with the statistical results $(10 \%)$ of China Family Panel Studies (CFPS 2012). Most of the religious people mainly belong to Buddhism, accounting for $4.8 \%$ of the total believers. The second highest proportion is Islam, accounting for about $2.3 \%$ of the total religious people. In contrast, the number of people who belong to Folk religion, Christianity, Catholicism, and Taoism is relatively small, accounting for $1.8 \%, 1.7 \%, 0.3 \%$, and $0.2 \%$ of the total religious people, respectively. Through further analysis, we found that the proportion of males and females in religious groups is relatively equal, but the proportion of female Buddhists is higher than that of male Buddhists. In terms of age, the proportion of religious people is relatively even in all age groups, and it is noted that the proportion of Buddhists over the age of $60(4.9 \%)$ is much higher than the other two age groups (3.1\% and $2.6 \%$ ). In terms of ethnicity, in the table, it can be seen that Hans account for $8.3 \%$ of the total religious groups and minorities only account for $2.4 \%$ of the total religious people. Additionally, we found that the proportion of Han Buddhists $(4.6 \%)$ is much higher than Minority Buddhists $(0.2 \%)$. In contrast, the proportion of Han Islam $(0.1 \%)$ is much lower than Minority Islam $(2.2 \%)$. In terms of regional differences, the religious people ratio of the rural population $(5.8 \%)$ is slightly higher than that of the urban population (4.9\%). In addition, we found that there are also clear differences among religious people in terms of education. As shown in Table 1, for most religions, the scale of religious people is gradually decreased with the improvement of education. This indicates that religious people are mainly focused on a lower level of education. Considering the specific position of housing, we also included it in our research. As shown in Table 1, we found that the proportion of religious people who own house property rights $(6.8 \%)$ is significantly higher than that who do not own house property rights (3.8\%), no matter whether Buddhism, Taoism, or other religious groups are considered. As shown in Table 1, we also found that the health status of religious people is relatively good as a whole. Religious people in good health account for a large proportion of the total religious people. It is worth noting that Table 1 does not list all sociodemographic variables and mainly focuses on several variables directly related to this research. 
Table 1. The result of descriptive analysis (mean/percentage).

\begin{tabular}{|c|c|c|c|c|c|c|c|c|}
\hline Variables & Non-Religion & Religious People & Buddhism & Taoism & Folk & Islam & Catholicism & Christianity \\
\hline \multicolumn{9}{|l|}{ Gender } \\
\hline Female $=0$ & $42.6 \%$ & $6.3 \%$ & $3.0 \%$ & $0.1 \%$ & $0.9 \%$ & $1.2 \%$ & $0.2 \%$ & $1.2 \%$ \\
\hline Male = 1 & $46.8 \%$ & $4.4 \%$ & $1.8 \%$ & $0.1 \%$ & $0.9 \%$ & $1.1 \%$ & $0.1 \%$ & $0.5 \%$ \\
\hline \multicolumn{9}{|l|}{ Age } \\
\hline Age $(6 \sim 44)=0$ & $25.3 \%$ & $2.6 \%$ & $1.1 \%$ & $0.1 \%$ & $0.4 \%$ & $0.8 \%$ & $0.1 \%$ & $0.4 \%$ \\
\hline Age $(44 \sim 59)=1$ & $28.6 \%$ & $3.1 \%$ & $1.3 \%$ & $0.1 \%$ & $0.7 \%$ & $0.6 \%$ & $0.2 \%$ & $0.5 \%$ \\
\hline Age $(60 \sim)=2$ & $35.5 \%$ & $4.9 \%$ & $2.4 \%$ & $0.1 \%$ & $0.6 \%$ & $0.9 \%$ & $0.1 \%$ & $1.0 \%$ \\
\hline \multicolumn{9}{|l|}{ Ethnicity } \\
\hline Minority $=0$ & $2.6 \%$ & $2.4 \%$ & $0.2 \%$ & $0.0 \%$ & $0.0 \%$ & $2.2 \%$ & $0.0 \%$ & $0.0 \%$ \\
\hline Han $=1$ & $86.7 \%$ & $8.3 \%$ & $4.6 \%$ & $0.2 \%$ & $1.7 \%$ & $0.1 \%$ & $0.3 \%$ & $1.7 \%$ \\
\hline \multicolumn{9}{|l|}{ Hukou } \\
\hline Rural & $48.4 \%$ & $5.8 \%$ & $2.5 \%$ & $0.2 \%$ & $0.7 \%$ & $1.2 \%$ & $0.1 \%$ & $1.2 \%$ \\
\hline Urban & $40.9 \%$ & $4.9 \%$ & $2.3 \%$ & $0.0 \%$ & $1.0 \%$ & $1.0 \%$ & $0.2 \%$ & $0.5 \%$ \\
\hline \multicolumn{9}{|l|}{ Education } \\
\hline Primary $=0$ & $30.3 \%$ & $5 \%$ & $2 \%$ & $0.1 \%$ & $0.7 \%$ & $1.3 \%$ & $0.1 \%$ & $1.0 \%$ \\
\hline Junior $=1$ & $26.8 \%$ & $2.9 \%$ & $1.4 \%$ & $0.1 \%$ & $0.4 \%$ & $0.5 \%$ & $0.1 \%$ & $0.5 \%$ \\
\hline Senior $=2$ & $17.4 \%$ & $1.6 \%$ & $0.8 \%$ & $0.1 \%$ & $0.3 \%$ & $0.2 \%$ & $0.1 \%$ & $0.2 \%$ \\
\hline College $=3$ & $14.9 \%$ & $1.2 \%$ & $0.6 \%$ & $0.0 \%$ & $0.3 \%$ & $0.2 \%$ & $0.0 \%$ & $0.1 \%$ \\
\hline \multicolumn{9}{|l|}{ Residence } \\
\hline Owned = 1 & $55.8 \%$ & $6.8 \%$ & $3.0 \%$ & $0.2 \%$ & $1.2 \%$ & $1.5 \%$ & $0.2 \%$ & $1.2 \%$ \\
\hline Borrowed $=2$ & $20.6 \%$ & $2.5 \%$ & $1.2 \%$ & $0.0 \%$ & $0.4 \%$ & $0.5 \%$ & $0.1 \%$ & $0.4 \%$ \\
\hline Rented $=3$ & $12.9 \%$ & $1.3 \%$ & $0.6 \%$ & $0.0 \%$ & $0.1 \%$ & $0.3 \%$ & $0.1 \%$ & $0.2 \%$ \\
\hline \multicolumn{9}{|l|}{ Health } \\
\hline Very Unhealthy = 1 & $2.4 \%$ & $0.4 \%$ & $0.1 \%$ & $0.0 \%$ & $0.1 \%$ & $0.0 \%$ & $0.0 \%$ & $0.1 \%$ \\
\hline Less Healthy = 2 & $11.6 \%$ & $1.8 \%$ & $0.8 \%$ & $0.1 \%$ & $0.3 \%$ & $0.4 \%$ & $0.0 \%$ & $0.4 \%$ \\
\hline Generally Healthy $=3$ & $16.8 \%$ & $2.1 \%$ & $1.2 \%$ & $0.1 \%$ & $0.4 \%$ & $0.2 \%$ & $0.1 \%$ & $0.3 \%$ \\
\hline Healthier $=4$ & $34.6 \%$ & $4.3 \%$ & $1.7 \%$ & $0.1 \%$ & $0.7 \%$ & $1.2 \%$ & $0.1 \%$ & $0.7 \%$ \\
\hline Very Healthy = 5 & $23.9 \%$ & $2.1 \%$ & $1.0 \%$ & $0.0 \%$ & $0.3 \%$ & $0.5 \%$ & $0.1 \%$ & $0.3 \%$ \\
\hline
\end{tabular}




\subsection{Group Differences in Religious Beliefs on Public Pro-Environmental Behavior}

This study showed that religious identity has a significant positive effect on public pro-environmental behavior $(\beta=0.14, p<0.01)$. On this basis, we continued to explore the group differences of religious identity on public pro-environmental behavior (as shown in Table 2). We used Ordered Probit Regression to test the relationship between religious identity on public pro-environmental behavior in different groups. First, we discussed the difference in the influence of religious identity on public pro-environmental behavior across gender and age (Model 1-Model $5)$. The results showed that women with a religious identity are more willing to practice public pro-environmental behavior than those without a religious identity $(\beta=0.17, p<0.01)$. In contrast, there is no significant difference between men's levels of public pro-environmental behavior $(\beta=0.11$, $p>0.05)$, regardless of whether they have a religious identity or not. The results suggest that religious identity, to a certain extent, improves women's attention and action on public pro-environmental behavior. However, men are more involved in public affairs. Therefore, the role of religion is not obvious to them. In terms of age, youth was not correlated with willingness to practice public pro-environmental behavior. We found that those middle-aged or older (over 45 years old) were more willing to practice public pro-environmental behavior. When growing older, people are more willing to practice public pro-environmental behavior (45-59 years old: $\beta=0.18, p<0.05$; over 60 years old: $\beta=0.26, p<0.01$ ). This may be closely related to the crisis of middle age, which promotes the individual's exploration of social value, life meaning, and religious concepts. This makes the middle-aged and elderly pay more attention to public environmental protection. Second, we explored the difference in the influence of religious identity on public pro-environmental behavior in hukou and households (Model 6-Model 10). We found that religious people are more willing to practice public pro-environmental behavior in both rural and urban settings (rural: $\beta=0.13, p<0.05$; urban: $\beta=0.14$, $p<0.05)$. The results indicate the important role of religious identity in rural regions. Under the guidance of religious identity, religious people who live in rural regions are liberated from family labor and pay attention to public environmental protection and take action. From the perspective of housing status, the results suggest that the religious people whose household property rights are their own or their spouses are more willing to practice public pro-environmental behavior than those without a religious identity and the religious people who have their own household property are more willing to practice public pro-environmental behavior than those without household property (owned house: $\beta=0.21, p<0.05$; borrowed house: $\beta=0.09, p>0.05$; rented house; $\beta=-0.13, p>0.05$ ), which indicates that there is an interaction between religious identity and household property. Although household occupies an important position in the view of Chinese people and individuals, values are deeply shaped by household, and individuals who have their own household property and do not have a religious identity are unwilling to practice public pro-environmental behavior. Although the environmental behavior of the public is deeply shaped by Chinese religion, individuals who have a religious identity and do not have their own household property are unwilling to practice public pro-environmental behavior. Finally, we will discuss the difference of religious identity on public pro-environmental behavior in terms of political status (Model 11-Model 12). The results show that political participants with a religious identity are more willing to practice public pro-environmental behavior than those without a religious identity $(\beta=0.23, p<0.01)$. Religious people who have political participation are more willing to practice public pro-environmental behavior $(\beta=0.23, p<0.01)$ and religious people who do not have political participation are unwilling to practice public pro-environmental behavior $(\beta=0.05, p>0.01)$. This indicates that there is an interaction between religion and politics. In other words, although politics emphasizes the concern for public affairs, if there is no stimulus of religion, political participants will not practice public pro-environmental behavior. Although religion is closely related to ecological protection, if there is no political participation, religious identity still has no effect on public pro-environmental behavior. To some extent, religion is closely related to politics, both of which emphasize the concern for public affairs. Only in the interaction of religion and politics are individuals willing to practice more environmental behaviors. 
Table 2. Ordered Probit Regression of religious identity on public pro-environmental behavior in different groups.

\begin{tabular}{|c|c|c|c|c|c|c|c|c|c|c|c|c|}
\hline \multirow{2}{*}{ Variables } & Model 1 & Model 2 & Model 3 & Model 4 & Model 5 & Model 6 & Model 7 & Model 8 & Model 9 & Model 10 & Model 11 & Model 12 \\
\hline & Female & Male & $\begin{array}{c}\text { Age } \\
(6 \sim 44)\end{array}$ & $\begin{array}{c}\text { Age } \\
(45 \sim 59)\end{array}$ & $\begin{array}{l}\text { Age } \\
(60 \sim)\end{array}$ & Rural & Urban & $\begin{array}{l}\text { Owned } \\
\text { House }\end{array}$ & $\begin{array}{c}\text { Borrowed } \\
\text { House }\end{array}$ & $\begin{array}{c}\text { Rented } \\
\text { House }\end{array}$ & Non-Voted & Voted \\
\hline $\begin{array}{l}\text { Religious } \\
\text { Identity }\end{array}$ & $\begin{array}{c}0.168^{* * *} \\
(2.71)\end{array}$ & $\begin{array}{l}0.106 \\
(1.59)\end{array}$ & $\begin{array}{l}-0.143 \\
(-1.57)\end{array}$ & $\begin{array}{c}0.179 * * \\
(2.23)\end{array}$ & $\begin{array}{c}0.263^{* * *} \\
(3.80)\end{array}$ & $\begin{array}{c}0.133^{* *} \\
(2.01)\end{array}$ & $\begin{array}{c}0.144^{* *} \\
(2.29)\end{array}$ & $\begin{array}{c}0.214^{* * *} \\
(3.84)\end{array}$ & $\begin{array}{l}0.085 \\
(0.87)\end{array}$ & $\begin{array}{l}-0.133 \\
(-1.00)\end{array}$ & $\begin{array}{l}0.052 \\
(0.83)\end{array}$ & $\begin{array}{c}0.231^{* * *} \\
(3.54)\end{array}$ \\
\hline Ethnicity & $\begin{array}{c}0.168^{*} \\
(1.71)\end{array}$ & $\begin{array}{c}0.325^{* * *} \\
(3.61)\end{array}$ & $\begin{array}{l}0.078 \\
(0.69)\end{array}$ & $\begin{array}{c}0.456^{* * *} \\
(3.67)\end{array}$ & $\begin{array}{c}0.265^{* *} \\
(2.34)\end{array}$ & $\begin{array}{l}0.164 \text { * } \\
(1.83)\end{array}$ & $\begin{array}{c}0.369^{* * *} \\
(3.78)\end{array}$ & $\begin{array}{c}0.365^{* * *} \\
(4.21)\end{array}$ & $\begin{array}{l}0.258^{*} \\
(1.75)\end{array}$ & $\begin{array}{l}-0.070 \\
(-0.47)\end{array}$ & $\begin{array}{c}0.201 * * \\
(2.29)\end{array}$ & $\begin{array}{c}0.297 * * * \\
(2.90)\end{array}$ \\
\hline Education & $\begin{array}{c}0.210^{* * *} \\
(7.58)\end{array}$ & $\begin{array}{c}0.189^{* * *} \\
(8.12)\end{array}$ & $\begin{array}{c}0.238^{* * *} \\
(6.89)\end{array}$ & $\begin{array}{c}0.280^{* * *} \\
(8.69)\end{array}$ & $\begin{array}{c}0.118^{* * *} \\
(4.17)\end{array}$ & $\begin{array}{c}0.174^{* * *} \\
(6.05)\end{array}$ & $\begin{array}{c}0.201^{* * *} \\
(8.57)\end{array}$ & $\begin{array}{c}0.195^{* * *} \\
(8.80)\end{array}$ & $\begin{array}{c}0.185^{* * *} \\
(4.59)\end{array}$ & $\begin{array}{c}0.247^{* * *} \\
(5.45)\end{array}$ & $\begin{array}{c}0.206^{* * *} \\
(8.50)\end{array}$ & $\begin{array}{c}0.200^{* * *} \\
(7.59)\end{array}$ \\
\hline $\mathrm{CPC}$ & $\begin{array}{c}0.176^{* *} \\
(2.29)\end{array}$ & $\begin{array}{c}0.193^{* * *} \\
(3.89)\end{array}$ & $\begin{array}{c}0.142 * \\
(1.74)\end{array}$ & $\begin{array}{c}0.191^{* *} \\
(2.49)\end{array}$ & $\begin{array}{c}0.199 * * * \\
(3.19)\end{array}$ & $\begin{array}{c}0.521^{* * *} \\
(6.45)\end{array}$ & $\begin{array}{l}0.068 \\
(1.41)\end{array}$ & $\begin{array}{c}0.129^{* * *} \\
(2.59)\end{array}$ & $\begin{array}{c}0.347^{* * *} \\
(3.69)\end{array}$ & $\begin{array}{c}0.229 * \\
(1.88)\end{array}$ & $\begin{array}{l}0.106^{*} \\
(1.76)\end{array}$ & $\begin{array}{c}0.204^{* * *} \\
(3.54)\end{array}$ \\
\hline Married & $\begin{array}{l}-0.114 \\
(-1.29)\end{array}$ & $\begin{array}{l}-0.041 \\
(-0.63)\end{array}$ & $\begin{array}{c}-0.112 \\
(-1.84)\end{array}$ & $\begin{array}{l}0.257 \\
(1.28)\end{array}$ & $\begin{array}{l}-0.215 \\
(-1.09)\end{array}$ & $\begin{array}{l}-0.092 \\
(-1.14)\end{array}$ & $\begin{array}{l}-0.045 \\
(-0.65)\end{array}$ & $\begin{array}{l}0.093 \\
(0.77)\end{array}$ & $\begin{array}{c}-0.239 * * * \\
(-2.87)\end{array}$ & $\begin{array}{l}0.010 \\
(0.10)\end{array}$ & $\begin{array}{l}-0.101 \\
(-1.63)\end{array}$ & $\begin{array}{l}-0.087 \\
(-0.85)\end{array}$ \\
\hline Work & $\begin{array}{l}0.015 \\
(0.28)\end{array}$ & $\begin{array}{l}-0.031 \\
(-0.67)\end{array}$ & $\begin{array}{l}0.072 \\
(1.00)\end{array}$ & $\begin{array}{l}-0.089 \\
(-1.46)\end{array}$ & $\begin{array}{l}-0.044 \\
(-0.72)\end{array}$ & $\begin{array}{l}-0.062 \\
(-1.23)\end{array}$ & $\begin{array}{l}0.028 \\
(0.55)\end{array}$ & $\begin{array}{l}-0.055 \\
(-1.28)\end{array}$ & $\begin{array}{l}0.079 \\
(0.99)\end{array}$ & $\begin{array}{l}0.016 \\
(0.16)\end{array}$ & $\begin{array}{l}-0.027 \\
(-0.55)\end{array}$ & $\begin{array}{l}0.005 \\
(0.10)\end{array}$ \\
\hline Income & $\begin{array}{c}0.064^{* * *} \\
(2.69)\end{array}$ & $\begin{array}{c}0.041 \text { * } \\
(1.96)\end{array}$ & $\begin{array}{l}-0.019 \\
(-0.60)\end{array}$ & $\begin{array}{c}0.074^{* *} \\
(2.53)\end{array}$ & $\begin{array}{c}0.091 * * * \\
(3.52)\end{array}$ & $\begin{array}{l}0.008 \\
(0.37)\end{array}$ & $\begin{array}{c}0.140^{* * *} \\
(5.46)\end{array}$ & $\begin{array}{c}0.052^{* * *} \\
(2.61)\end{array}$ & $\begin{array}{c}0.056^{*} \\
(1.71)\end{array}$ & $\begin{array}{l}0.065 \\
(1.42)\end{array}$ & $\begin{array}{c}0.083^{* * *} \\
(3.81)\end{array}$ & $\begin{array}{l}0.028 \\
(1.25)\end{array}$ \\
\hline Health & $\begin{array}{c}0.037^{*} \\
(1.72)\end{array}$ & $\begin{array}{l}0.028 \\
(1.46)\end{array}$ & $\begin{array}{l}-0.030 \\
(-0.97)\end{array}$ & $\begin{array}{l}-0.030 \\
(-1.21)\end{array}$ & $\begin{array}{c}0.096^{* * *} \\
(4.45)\end{array}$ & $\begin{array}{l}0.024 \\
(1.22)\end{array}$ & $\begin{array}{c}0.040 \text { * } \\
(1.94)\end{array}$ & $\begin{array}{l}0.023 \\
(1.32)\end{array}$ & $\begin{array}{c}0.080^{* *} \\
(2.52)\end{array}$ & $\begin{array}{l}0.005 \\
(0.12)\end{array}$ & $\begin{array}{l}0.024 \\
(1.20)\end{array}$ & $\begin{array}{l}0.040 \text { * } \\
(1.95)\end{array}$ \\
\hline EK & $\begin{array}{c}0.087^{* * *} \\
(7.35)\end{array}$ & $\begin{array}{c}0.065^{* * *} \\
(6.12)\end{array}$ & $\begin{array}{l}0.025 \\
(1.62)\end{array}$ & $\begin{array}{c}0.075^{* * *} \\
(5.50)\end{array}$ & $\begin{array}{c}0.107^{* * *} \\
(8.56)\end{array}$ & $\begin{array}{c}0.104^{* * *} \\
(9.35)\end{array}$ & $\begin{array}{c}0.046^{* * *} \\
(4.10)\end{array}$ & $\begin{array}{c}0.073^{* * *} \\
(7.60)\end{array}$ & $\begin{array}{c}0.095^{* * *} \\
(5.40)\end{array}$ & $\begin{array}{c}0.049^{* *} \\
(2.30)\end{array}$ & $\begin{array}{c}0.065^{* * *} \\
(5.89)\end{array}$ & $\begin{array}{c}0.087^{* * *} \\
(7.72)\end{array}$ \\
\hline $\mathrm{N}$ & 3689.000 & 4437.000 & 2169.000 & 2650.000 & 3307.000 & 4262.000 & 3864.000 & 5232.000 & 1737.000 & 1157.000 & 4362.000 & 3764.000 \\
\hline Pseudo $R^{2}$ & 0.064 & 0.043 & 0.040 & 0.055 & 0.055 & 0.039 & 0.035 & 0.052 & 0.071 & 0.041 & 0.057 & 0.053 \\
\hline LR $\mathrm{chi}^{2}$ & 574.58 & 508.06 & 258.97 & 376.90 & 402.06 & 337.56 & 410.81 & 697.45 & 317.21 & 118.45 & 628.00 & 521.61 \\
\hline
\end{tabular}




\subsection{The Mediating Effect of Environmental Risk Perception}

This section uses the non-parametric percentile bootstrap method of deviation correction recommended by Wen and Ye (2014) to test the mediating effect of environmental risk perception. In this study, 5000 samples were taken repeatedly. In terms of the specific inspection and methods, the study used the SPSS macro PROCSS plug-in developed by Hayes. We chose Model 4 to test the mediating effect of environmental risk perception between religious identity and public pro-environmental behavior on the basis of controlling individual social demographic and personal characteristics such as gender, age, ethnicity, education, income, hukou, political status, housing status, working status, marital status, health, and environmental knowledge.

As shown in Table 3, the results of the mediating effect model show that religious identity has a significant positive effect on public pro-environmental behavior $(\beta=0.18, p<0.01, \mathrm{C} 1=[0.06,0.29])$. Religious identity has a significant positive effect on environmental risk perception $(\beta=1.03, p<0.01$, $\mathrm{C} 1=[0.29,1.76])$, and environmental risk perception also has a statistically significant positive effect on public pro-environmental behavior $(\beta=0.01, p<0.01, \mathrm{C} 1=[0.01,0.01])$. This suggests that environmental risk perception plays a part in the mediating role between religious identity and public pro-environmental behavior. We used Bootstrap to estimate the interval of the mediating effect. The results (Figure 1) indicate that the value of the mediating effect of environmental risk perception is $0.01(95 \% \mathrm{CI}=[0.00,0.02])$, and the confidence interval does not contain 0 . It can be considered that the mediating effect of environmental risk perception is credible, which accounts for $6 \%$ of the total effect. This indicates that the influence of religious identity on public pro-environmental behavior is partly due to the role of environmental risk perception. People with a religious identity have a higher environmental risk perception. Accordingly, the higher the perception of environmental risk, the higher the frequency of practicing public pro-environmental behavior.

Table 3. Regression analysis of variables in the model.

\begin{tabular}{cccccccccccc}
\hline \multicolumn{2}{c}{ Regression Equation } & \multicolumn{3}{c}{ Overall Fit Index } & \multicolumn{5}{c}{ Sig. of Regression Coefficient } \\
\hline $\begin{array}{c}\text { Dependent } \\
\text { Variables }\end{array}$ & $\begin{array}{c}\text { Independent } \\
\text { Variables }\end{array}$ & $\mathbf{R}$ & $\mathbf{R}^{\mathbf{2}}$ & $\mathbf{F}$ & Coeff & $\boldsymbol{t}$ & $\boldsymbol{p}$ & LLCI & ULCI \\
\hline PEB & Religious Identity & 0.33 & 0.11 & 75.17 & 0.18 & 2.99 & 0.00 & 0.06 & 0.29 \\
ERP & Religious Identity & 0.20 & 0.04 & 24.37 & 1.03 & 2.75 & 0.00 & 0.29 & 1.76 \\
PEB & ERP & 0.33 & 0.11 & 70.70 & 0.01 & 5.19 & 0.00 & 0.01 & 0.01 \\
\hline
\end{tabular}

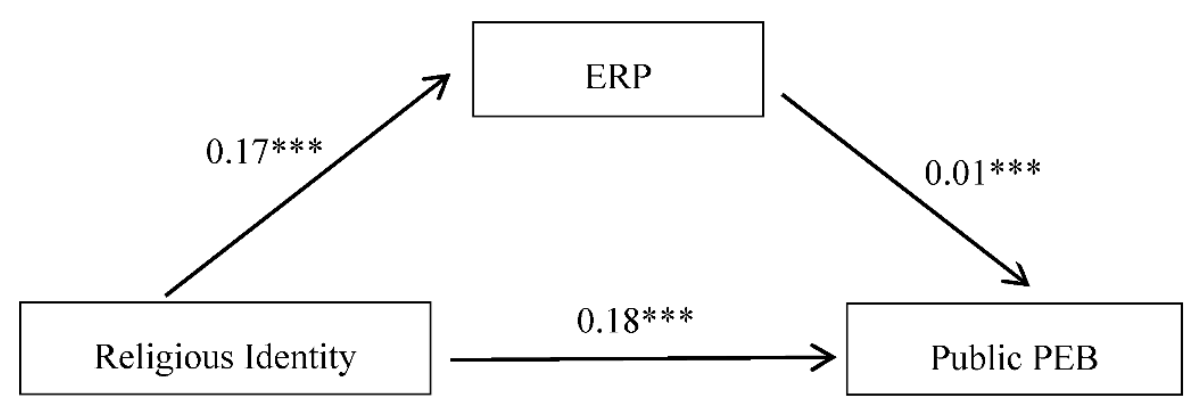

Figure 1. Mediation model of environmental risk perception. $t$ statistics in parentheses; ${ }^{* * *} p<0.01$ (two-tailed tests).

\section{Discussion and Conclusions}

Compared with Western research on the relationship between religion and the environment, research on that relationship in China still seems to be relatively insufficient. Since the 1960s, Western scholars have been exploring the complex relationship between religion and the environment (White 1967). In the past 50 years, a large number of studies have emerged, which make up for the gap in the study of the relationship between religion and the environment. In China, the discussion about the relationship between religion and the environment only started to appear in the past 20 years. 
Some people may wonder why we do not use Western research paradigms directly to interpret the internal relationship between religion and the environment in China. It must be noted that China's special national conditions mean that we cannot directly copy the Western research studies. China is an atheist country. The Communist Party of China is the ruling party and a firm supporter of Marxism. Social individuals are firmly instilled with socialist values and materialistic beliefs. With the cultivation of China's political system and traditional culture, relatively few people have a religious identity. This does not mean that China's religion is not important. China implements the policy of freedom of religious belief, which provides a unique developmental environment for religion and also provides a unique perspective for studying religion. Under the circumstance of increasingly severe environmental degradation, we should try our best to investigate the significance of religion for environmental protection. The correct way to do this is to absorb previous research and expand research on religion and environmental behavior in the context of China. In this article, we mainly use religious identity as a predictor of religion. After carefully reviewing the current studies on religion and environmental behavior in China and the West, we found that some scholars have focused on the natural relationship between religion and environmental behavior (Woodhouse et al. 2015; Du et al. 2014; Yang and Huang 2018). However, whether there are group differences in the influence of religion on environmental behavior remains to be further discussed. We have confirmed in our research that religious identity has no significant positive effect on private pro-environmental behavior. Therefore, in this article, we will further deepen the research on religious identity and the environment and mainly focus on exploring the group differences in the religious identity impact on public pro-environmental behavior and the internal mechanism of religious identity's impact on public pro-environmental behavior.

Based on the data of the Chinese General Social Survey in 2013, this paper took religious identity as the independent variable and public pro-environmental behavior as the dependent variable. Simultaneously, we controlled sociodemographic variables which could have strong connections with public pro-environmental behavior, such as gender, age, ethnicity, education, hukou, income, political status, housing status, working status, marital status, health, and environmental knowledge (EK). After controlling these variables, we mainly discussed the differences in gender, age, hukou, household, and political status in the impact on religious identity and public pro-environmental behavior. Considering the unique role of risk perception in religion and environmental behavior, we regard environmental risk perception as a mediator of religious identity and public pro-environmental behavior and we analyzed it in this paper.

First, we found that women who have a religious identity participate in more public pro-environmental behavior than those without a religious identity. However, regardless of whether men have a religious identity or not, there is no significant difference in participating in public pro-environmental behavior. Previous studies have shown that because of the influence of the traditional notion that " men's work centers around outside, women's work centers around inside", women are more likely to deal with environmental issues related to family affairs compared to men, while public pro-environmental behaviors are less involved (Xiao and Hong 2010). This study further confirmed that not all women are indifferent to public pro-environmental behavior. Women who have a religious identity are more concerned about public pro-environmental behavior. Religious groups frequently encourage religious people to participate in some activities. In the process, religious people are endowed with shared values and consistent goals and actions. Driven by values, women's attention shifts from family activities to public pro-environmental behavior. In contrast, men themselves are the main participants in social public affairs, which makes them more willing to support public environmental protection. In other words, the stimulating effect of religion on men's participation in public pro-environmental behavior is not as obvious as that of women.

Second, we found that there are age differences in the influence of religious identity on public pro-environmental behavior. On the one hand, religious identity has no significant effect on public pro-environmental behavior among religious people under 45 . On the other hand, religious identity has a significant impact on public pro-environmental behavior among religious people over the age 
of 45 . This conclusion is contrary to Chen et al.'s. They thought that the younger one is, the more willing one is to participate in public pro-environmental behavior (Chen et al. 2011). We think this may be related to China's national conditions. In China, individuals under the age of 45 are mainly in the period of life of career development. In this period, individuals face much pressure in work and life, which can suppress the stimulation of religion on individuals. When one is over 45 , an individual's career and family are generally more stable. The main aim in this period is to pursue a higher status and prestige. Obviously, participating in public pro-environmental behavior is a great way to achieve this goal. In addition, most of these individuals have the time and ability to engage in public pro-environmental behavior. Inspired by religion, individuals in this period are more willing to engage in public pro-environmental behavior. Especially when individuals are over the age of 60, they hope to realize their own life meaning and social value, and religion affirms that participating in public pro-environmental behavior is an important way to achieve life meaning and social value. Therefore, middle-aged and old people with a religious identity are more willing to participate in public pro-environmental behavior.

Third, we found that regardless of whether one focuses on rural or urban inhabitants, religious people are more willing to engage in public pro-environmental behavior. Chen et al. (2011) pointed out in their research that urban populations are more willing to participate in pro-environmental behavior. Obviously, our research further confirms their findings. Whether people engage in public pro-environmental behavior or not, religion is definitely a good catalyst. Due to the impact of religion, rural populations gradually hold fewer traditional concepts and become more public-minded. However, the majority of rural people without a religious identity tend to have narrower egos. Just as the saying goes, "Each one minds his own business, doesn't bother about the frost on his neighbor's roof." In contrast, since most urban people have higher incomes and a higher education, they have a higher awareness of environmental protection and are more willing to engage in public pro-environmental behavior. Because of the impact of religion, urban people further deepen their understanding of environmental protection on a moral level and are more willing to turn environmental protection into actual public pro-environmental behavior.

Fourth, we found that there are household differences in the impact of religious identity on public pro-environmental behavior. Specifically speaking, religious people who have their own household property are more willing to engage in public pro-environmental behavior. However, religious people who do not have household property are less engaged in public pro-environmental behavior than those with housing property rights. Some studies have confirmed that individuals living in family environments are more willing to participate in environmental behavior, while those living in hotels are not willing to engage in environmental behavior ( $\mathrm{Li}$ and Wei 2013). Obviously, our research further revised and expanded their research findings. In our study, we found that household property owners who have a religious identity are more willing to engage in public pro-environmental behavior than those without a religious identity. This indicates that there is an interaction between religion and household property. Religion identity does not directly affect public pro-environmental behavior. According to the research findings, we suggest that religious identity is more like a stimulus. Under its stimulation, religious people who have their own household property are more willing to participate in public pro-environmental behavior. It is noted that household occupies an important position in the view of Chinese people and individuals' values are deeply shaped by household. In ancient times, there was the saying "live and work in peace." When the household property rights belong to individuals or their spouse's, they will develop self-discipline consciousness and are responsible for the house and surrounding environment. Individuals who have their own household property may be sensitive to the surrounding environment and are more willing to engage in private pro-environmental behavior. Inspired by religion, their pro-environmental behavior will gradually expand from private to public. In contrast, religious people who do not have their own household property are busy with their personal livelihood. It is obvious that the stimulating effect of religion on them is not enough to transform their public pro-environmental concern to public pro-environmental behavior. It also 
indicates that household property is a potential mediator of the religious identity impact on public pro-environmental behavior. In the future, we will explore the specific role of household in religion and pro-environmental behavior.

Fifth, we found that political participants with a religious identity are more willing to participate in public pro-environmental behavior than those without a religious identity and religious people who exhibit political participation are more willing to engage in public pro-environmental behavior. Some scholars have confirmed that there is a connection between religion and politics (Yang and Huang 2018). It is not too difficult to find that political participants will pay attention to various public issues, including environmental protection. Under the stimulation of religion, the attention of political participants paid to the public pro-environment will be turned into actual action. In a sense, religion and politics are interdependent. Therefore, political participation is also an important potential mediator. In the future, we will fully explore the internal mechanism of political participation in religion and public pro-environmental behavior.

Lastly, we tested the mediating effect of environmental risk perception. We found that environmental risk perception can act as a partial mediator. To some extent, the findings confirm the specific role of risk perception in religion and pro-environmental behavior. That is, religious identity indirectly affects the public pro-environmental behavior via affecting the environmental risk perception. When religious people have a higher environmental risk perception, this high environmental risk perception can easily transform into environmental behavior to prevent risks. As is known to all, different perceptions of environmental risk will lead to different environmental behaviors. Environmental risk perception is more related to whether the individual's environmental concerns can be transformed into real environmental behavior. Some individuals may have high environmental concerns, but they will not engage in environmental behavior. For religious people, they pay more attention to public environmental issues and they are more sensitive to public environmental risk. Therefore, once they display a higher public environmental risk, they will quickly turn their environmental concerns into public pro-environmental behaviors.

Our research is quite encouraging and promising. The complex positive relationship between religious identity and public pro-environmental behavior provides an important reference for the construction of ecological civilization. In a word, whether it is the new environmental paradigm in the West or "Tianren Heyi" in China, religion is deeply embedded in the local cultural background and is shaped by politics and society. Even if two people self-identify as having the same religion, their willingness to engage in public pro-environmental behavior will vary greatly because of different economic, social, cultural, and political backgrounds. When we explore the relationship between religious identity and public pro-environmental behavior, we should not separate religious identity from other factors. In the final analysis, religious identity is not a determining factor, but an influencing factor. When the time is ripe, religious identity will strengthen public pro-environmental behavior. This study has its limitations. First of all, we employed cross-sectional data to study the relationship between religious identity and public pro-environmental behavior in the Chinese context. This only depicted the relationship between these two variables at the node in 2013. Our research has not yet answered whether the relationship has changed over time, because CGSS is not tracking data. In future research, we will attempt to adopt panel data to examine the changing trend of this relationship and use different datasets to compare our findings. Second, we mainly calculated the value of each variable by summation. This only depicted the general trend between these two variables. In future research, we will attempt to conduct an analysis to further test the relationship between religion and public pro-environmental behavior. Third, the proportion of Chinese religion is relatively small. Religious people only account for $10 \%$ of the total population in China (CFPS 2012). Although the scale of religious people in China cannot be underestimated based on the current population of 1.4 billion, under the limitation of current data, there are only 976 religious samples we can use, which include 439 religious people who belong to Buddhism, 22 religious people who belong to Taoism, 156 religious people who belong to Folk, and 359 religious people who belong to other religious groups. 
This means that the existing data scale cannot support us in conducting a more detailed classification and comparison of religions (i.e., Buddhism, Taoism, and other religious groups). In the future, we will further explore the relationship between religion and public pro-environmental behavior in China in more detail and depth, and will also include the different influences of Buddhism, Taoism, and other religious groups under the premise of more abundant data.

Author Contributions: Conceptualization, S.Z. and L.W.; methodology, S.Z; software, S.Z; validation, S.Z., L.W. and T.L.; formal analysis, S.Z.; investigation, S.Z.; resources, S.Z.; data curation, S.Z.; writing-original draft preparation, S.Z.; writing-review and editing, S.Z.; visualization, S.Z.; supervision, S.Z.; project administration, S.Z.; funding acquisition, L.W. All authors have read and agreed to the published version of the manuscript.

Funding: This research was funded by [the National Social Science Foundation of China] grant number [18VZL009] and the APC was funded by [18VZL009].

Conflicts of Interest: The authors declare no conflict of interest.

\section{References}

Baan, Paul J. A., and Frans Klijn. 2004. Flood risk perception and implications for flood risk management in the Netherlands. International Journal of River Basin Management 2: 113-22. [CrossRef]

Beisner, E. Calvin. 2001. Review: Where Garden Meets Wilderness: Evangelical Entry into the Environmental Debate. Nova Religio: The Journal of Alternative and Emergent Religions 2: 362-63.

Berry, Evan. 2013. Religious Environmentalism and Environmental Religion in America. Religion Compass 10: 454-66. [CrossRef]

Bubeck, Philip, Willem Jan Wouter Botzen, and Jeroen Cjh Aerts. 2012. A Review of Risk Perceptions and Other Factors that Influence Flood Mitigation Behavior. Risk Analysis 9: 1481-95. [CrossRef] [PubMed]

Catton, William R., Jr., and Riley E. Dunlap. 1978. Environmental Sociology: A New Paradigm. American Sociologist 1: 41-49.

Chinese Family Panel Studies (CFPS). 2012. Available online: http://www.isss.pku.edu.cn/cfps/EN/Data/2012/244. html (accessed on 16 August 2017).

CGSS. 2013. Chinese General Social Survey (中国综合社会调查). Available online: http://www.chinagss.org/index. php?r=index/publication (accessed on 17 July 2017).

Chen, Xiaodong, M. Nils Peterson, Vanessa Hull, Chuntian Lu, Graise D. Lee, Dayong Hong, and Jianguo Liu. 2011. Effects of attitudinal and sociodemographic factors on pro-environmental behaviour in urban China. Environmental Conservation 1: 45-52. [CrossRef]

Chester, David. K., Angus M. Duncan, and Christopher J. L. Dibben. 2008. The importance of religion in shaping volcanic risk perception in Italy, with special reference to Vesuvius and Etna. Journal of Volcanology and Geothermal Research 3-4: 216-28. [CrossRef]

Chinese Taoist Association. 2009. Eight-Year (2010-2017) Planning for Environmental Protection in China (中 国道教界保护环境的八年规划 2010-2017). Available online: http://www.arcworld.org/downloads/Daoist8YPChinese.pdf (accessed on 17 November 2017).

Clements, John M., Aaron M. McCright, and Chenyang Xiao. 2014. Green Christians? An Empirical Examination of Environmental Concern within the U.S. General Public. Organization and Environment 1: 85-102. [CrossRef]

Corral-Verdugo, Victor, and Luz Irene Armendariz. 2000. The "New Environmental Paradigm" in a Mexican Community. The Journal of Environmental Education 3: 25-31. [CrossRef]

Du, Xingqiang, Wei Jian, Quan Zeng, and Yingjie Du. 2014. Corporate Environmental Responsibility in Polluting Industries: Does Religion Matter? Journal of Business Ethics 3: 485-507. [CrossRef]

Dunlap, Riley E., and Kent D. Van Liere. 2008. The "New Environmental Paradigm". Journal of Environmental Education 1: 19-28. [CrossRef]

Dunlap, Riley E., Kent D. Van Liere, Angela G. Mertig, and Robert Emmet Jones. 2000. New Trends in Measuring Environmental Attitudes: Measuring Endorsement of the New Ecological Paradigm: A Revised NEP Scale. Journal of Social Issues 3: 425-42. [CrossRef]

Eckberg, Douglas Lee, and T. Jean Blocker. 1989. Varieties of Religious Involvement and Environmental Concerns: Testing the Lynn White Thesis. Journal for the Scientific Study of Religion 4: 509-17. [CrossRef] 
Hadler, Markus, and Max Haller. 2011. Global activism and nationally driven recycling: The influence of world society and national contexts on public and private environmental behavior. International Sociology 3: 315-45. [CrossRef]

Haluza-Delay, Randolph. 2000. Green Fire and Religious Spirit. Journal of Experiential Education 3: $143-49$. [CrossRef]

Harper, Fletcher, and Stacey Kennealy. 2009. Greening Our Faith: Putting Belief into Action. Anglican Theological Review 4: 619.

Harris, Paul G. 2006. Environmental perspectives and behavior in China: Synopsis and bibliography. Environment and Behavior 1: 5-21. [CrossRef]

Hayes, Bernadette C., and Manussos Marangudakis. 2000. Religion and Environmental Issues within Anglo-American Democracies. Review of Religious Research 2: 159-74. [CrossRef]

Hoffman, Andrew J., and Lloyd E. Sandelands. 2005. Getting right with nature: Anthropocentrism, ecocentrism, and theocentrism. Organization and Environment 2: 141-62. [CrossRef]

Kearns, Laurel. 1996. Saving the Creation: Christian Environmentalism in the United States. Sociology of Religion 1: 55. [CrossRef]

Li, Haimei, and Changwen Chen. 2010. Analysis on the Source of the Decline of Taoism Based on the Difference between Oriental and Western Religious Perspectives. N. W. Journal of Ethnology 3: 56-60, 67. (In Chinese).

Lindell, Michael K., and Seong Nam Hwang. 2008. Households' perceived personal risk and responses in a multihazard environment. Risk Analysis 2: 539-56. [CrossRef] [PubMed]

Lu, Yunfeng. 2008. Beyond the Sociology of Christianity: Probing the applicability of the religious economy model to China. Sociological Study 5: 81-97, 244. (In Chinese).

White, Lynn, Jr. 1967. The Historical Roots of Our Ecologic Crisis Lynn. Science 3767: 1203-7. [CrossRef] [PubMed]

Maloney, Michael P., Michael P. Ward, and G. Nicholas Braucht. 1975. A revised scale for the measurement of ecological attitudes and knowledge. American Psychologist 7: 787-90. [CrossRef]

Li, Miao, and Wei Wei. 2013. Consumers' pro-environmental behavior and the underlying motivations: A comparison between household and hotel settings. International Journal of Hospitality Management 1: 102-12.

Miller, Alan S., and John P. Hoffmann. 1995. Risk and religion: An explanation of gender differences in religiosity. Journal for the Scientific Study of Religion 1: 63-75. [CrossRef]

Miller, James, Dan Smyer Yu, and Peter van der Veer, eds. 2014. Religion and Ecological Sustainability in China. Amsterdam: Routledge.

Noussair, Charles N., Stefan T. Trautmann, Gijs van de Kuilen, and Nathanael Vellekoop. 2013. Risk aversion and religion. Journal of Risk and Uncertainty 2: 165-83. [CrossRef]

O'Connor, Robert E., Richard J. Bord, and Ann Fisher. 1999. Risk perceptions, general environmental beliefs, and willingness to address climate change. Risk Analysis 3: 461-71. [CrossRef]

Pew Research Center. 2012. The Global Religious Landscape: Christians. Available online: http://www.pewforum. org/2012/12/18/global-religious-landscape-christians/ (accessed on 17 September 2017).

Pickering, Kathleen, and Benjamin Jewell. 2008. Nature is Relative: Religious Affiliation, Environmental Attitudes, and Political Constraints on the Pine Ridge Indian Reservation. Journal for the Study of Religion, Nature and Culture 1: 135-58. [CrossRef]

Plapp, Tina, and Ute Werner. 2006. Understanding risk perception from natural hazards: Examples from Germany. In RISK21-Coping with Risks Due to Natural Hazards in the 21st Century. Boca Raton: CRC Press, pp. 111-18.

Plattner, Th, Tina Plapp, and Bernd Hebel. 2006. Integrating public risk perception into formal natural hazard risk assessment. Natural Hazards and Earth System Sciences 6: 471-83. [CrossRef]

The State Administration for Religious Affairs (SARA). 2014. Notice on Further Promoting Civilization in Burning Incense and Construction of Ecological Temple (关于进一步推动文明敬香、建设生态寺观工作的通知). Available online: http://www.sara.gov.cn/old/xxgk/gsgg/58220.htm (accessed on 17 November 2017).

Sherkat, Darren E., and Christopher G. Ellison. 2007. Structuring the religion-environment connection: Identifying religious influences on environmental concern and activism. Journal for the Scientific Study of Religion 1: 71-85. [CrossRef]

Slimak, Michael W., and Thomas Dietz. 2006. Personal values, beliefs, and ecological risk perception. Risk Analysis 6: 1689-705. [CrossRef] [PubMed]

Slovic, Paul. 1999. Trust, emotion, sex, politics, and science: Surveying the risk-assessment battlefield. Risk Analysis 4: 689-701. [CrossRef] 
Slovic, Paul, and Ellen Peters. 2006. Risk perception and affect. Current Directions in Psychological Science 6: 322-25. [CrossRef]

Smith, Angela M., and Simone Pulver. 2009. Ethics-based environmentalism in practice: Religious-environmental organizations in the United States. Worldviews: Environment, Culture, Religion 2: 145-79. [CrossRef]

Terpstra, Teun, Michael K. Lindell, and Jan M. Gutteling. 2009. Does communicating (flood) risk affect (flood) risk perceptions? Results of a quasi-experimental study. Risk Analysis: An International Journal 8: 1141-55. [CrossRef]

Tong, Defu. 2005. A Comparison between Chinese and Western View of Religion. Journal of the Central University for Nationalities (Philosophy and Social Sciences Edition) 1: 39-48. (In Chinese).

Wallace, Mark I. 2008. The New Green Christianity: Why The Church Is Vital To Saving The Planet. Word and World 1: 75.

Wen, Zhonglin, and Baojuan Ye. 2014. Analyses of Mediating Effects: The Development of Methods and Models. Advances in Psychological Science 5: 731-45. [CrossRef]

Win-Gallup International. 2012. Global Index of Religiosity and Atheism. Available online: http://www.wingia. com/web/files/news/14/file/14.pdf (accessed on 17 September 2017).

Woodhouse, Emily, Martin A. Mills, Philip J. K. McGowan, and E. J. Milner-Gulland. 2015. Religious relationships with the environment in a Tibetan rural community: Interactions and contrasts with popular notions of indigenous environmentalism. Human Ecology 2: 295-307. [CrossRef]

Woodrum, Eric, and Michelle J. Wolkomir. 1997. Religious effects on environmentalism. Sociological Spectrum 2: 223-34. [CrossRef]

Xi, Jinping. 2013. Promote Friendship Between Our People and Work Together to Build a Bright Future. Available online: http://politics.people.com.cn/n/2013/0908/c1024-22845281.html (accessed on 8 September 2013).

Xiao, Chenyang, and Dayong Hong. 2010. Gender differences in environmental behaviors in China. Population and Environment 1: 88-104. [CrossRef]

Xing, Yijun, and Mark Starik. 2017. Taoist leadership and employee green behaviour: A cultural and philosophical microfoundation of sustainability. Journal of Organizational Behavior 9: 1302-19. [CrossRef]

Xinhua. 2016. Current Politics: Jianyong Jiang meets with Matian Peng, Secretary General of the World Religion and Environmental Protection Foundation and his delegation. Xinhua News. (蒋坚永会见世界宗教与环境保护基 金会秘书长彭马田一行). Available online: http://www.xinhuanet.com/politics/2016-12/07/C_129393856.htm (accessed on 7 December 2016).

Yang, Yu, and Shizhi Huang. 2018. Religious beliefs and environmental behaviors in China. Religions 3: 1-12.

Yao, Xinzhong. 2014. An Eco-Ethical Interpretation of Confucian "Tianren Heyi". Frontiers of Philosophy in China 4: 570-85.

Zhang, Zhigang. 2016. Qian Mu's Religious Views and the Comparison of Chinese and Western Cultures. Journal of Beifang University of Nationalities 6: 5-12. (In Chinese).

(C) 2020 by the authors. Licensee MDPI, Basel, Switzerland. This article is an open access article distributed under the terms and conditions of the Creative Commons Attribution (CC BY) license (http://creativecommons.org/licenses/by/4.0/). 